\title{
Die betekenis van die filosofie vir die teologie volgens Barth en Paul Tillich
}

\author{
F J VAN ZYL
}

\section{Inleiding}

Dwarsdeur die ganse tyd van sy bestaan het die Christelike teologie op een of ander wyse met die filosofie te doen gehad. Dis ook maklik aan te toon hoe dat hulle mekaar voortdurend wedersyds beïnvloed het. Hulle verbintenis en aanraking met mekaar het deur die eeue verskillende gestaltes aangeneem en was nie altyd ewe vriendelik nie. Die heel eerste ontmoeting van die teologie met die filosofie het die gestalte van konfrontasie aangeneem. Toe die filosoof, Celsus, omstreeks die jaar $180 \mathrm{n} \mathrm{C}$, as die mees kompetente woordvoerder van die Grieks-heidense filosofie van sy tyd, die enige waarheid wat die kerk verkondig, prinsipieel weerlê het, kom die apologete na vore ter verdediging van die Christelike waarheid. Weliswaar het die verdediging van die Christelike waarheid deur die apologete self sterk onder invloed van die hellenistiese filosofie gestaan en het hulle ook die Christendom as die ware filosofie beskou, nogtans moet ons hierdie apologete beskou as die eerste beoefenaars van die Christelike teologie, al noem Karl Heussí dit ook 'n "primitiewe teologie". (Kompendium der Kirchengeschichte, 12a).

Hoewel die eerste ontmoeting tussen teologie en filosofie die vorm van konfrontasie aangeneem het, beteken dit geensins dat daar nie ook tye van oorvriendelikheid teenoor die filosofie was nie. Hierdie tye was vir die teologie egter nie altyd goeie tye nie. Nie alleen het dit tot ongeoorloofde flirtasie met die filosofie aanleiding gegee nie, maar dit het ook gelei tot 'n "smadelike afhanklikheid" (van Niftrik, SOLA FIDEI, p 312), dit wil sê tot subordinasie van die teologie aan die filosofie. ' $n$ Mens hoef hier alleen maar te dink aan die 19de eeuse teologie waarin nie meer die openbaring nie, maar die godsdiens uitgangspunt van die teologie geword het. Die filosofie het bepaal wat die wese van die godsdiens is, en aan die teologie is die taak gestel om die bepaalde uiting van die algemene wese in die afsonderlike godsdienste te bestudeer. Die Christelike teologie moet hom dus besig hou met die Christelike godsdiens as besondere gestalte van die algemene wese van die godsdiens.

Met hierdie toedrag van sake was manne soos Brunner en Barth egter nie tevrede nie. Hulle het daarteen geprotesteer dat die teologie ' $n$ beperkte gebied toegewys word binne' $n$ filosofies bepaalde waar- 
heidsgebied. Eintlik moet dit volgens hulle net andersom wees: die filosofie is ' $n$ sinvolle menslike werksaamheid binne die openbaring. Albei het dan ook gestry om die teologie van filosofiese oorheersing te bevry. Wesenlik is die teologie bereid om aan almal nederige diens te verrig, maar hierdie diens is gerig op die een, enige waarheid wat nie in 'n mens opkom nie, maar na jou toe kom, dus nie die waarheid wat in rede-immanente denke gegrond is nie, maar die waarheid wat geopenbaar is in Hom wat gesê het: Ek is die waarheid... Brunner het sy teologiese taak daarin gesien dat hy die Reformatoriese teologie van alle filosofiese smet moet suiwer. Dit het by hom dan ook gelei tot wat ons kan noem 'n voortdurende disputasie met die filosofie. Hy noem dit die "andere Aufgabe" van die teologie en bring dit tuis onder die begrip Eristiek, twisgesprek. Vanselfsprekend was daar teoloë wat anders oor die verhouding tussen filosofie en teologie gedink het as die dialektiese teoloë. Hulle het gepoog om die gespanne verhouding tussen die twee te besweer deur 'n rekonsiliasie te probeer bewerk. Wat hierdie groep betref, wil ons besonderlik stilstaan by Paul Tillich. Wat die ander betref, die wat meer geneig tot konfrontasie en disputasie is, wil ons besonderlik gaan luister na Karl Barth.

\section{Karl Barth}

Nêrens het Barth duideliker gespreek oor die verhouding tussen filosofie en teologie as in die "Festschrift" vir sy broer, Heinrich Barth (Philosophie und Christeliche Existenz, 1960, bl 93-107). Om van 'n teenstelling tussen filosofie en teologie te praat, is volgens hom 'n abstraksie. Dit gaan eerder om verskillende mense wat verskillend geïnteresseerd is, verskillende verpligtings het en op verskillende maniere besig is. Hoewel hulle op verskillende maniere besig is, moet teoloog en filosoof mekaar beskou as mense wat met die een, enige waarheid gekonfronteer is. Albei moet onthou dat hulle nie oor hierdie waarheid beskik nie, maar dit slegs kan dien. Die een kan hom dan ook nooit superieur bokant die ander beskou nie. In sy prolegomena tot die Kirchliche Dogmatik het Barth reeds daarop gewys dat die teologiese spreke nooit 'n saak van menslike voortreflikheid kan wees nie. Elke sweem van menslike roem is uitgesluit. Teologiese spreke is ' $n$ saak van goddelike genade, juis daarom is die roem uitgesluit. Die teoloog sê wel iets besonders, maar wat hy sê, kan nooit so gesê word dat die filosoof dit nie ook sou kon sê nie. Hy beskik oor geen menslike bekwaamheid of vermoë om iets anders as die filosoof te sê nie. Wat sy menslike waardigheid of vermoë betref, het Barth iewers verwys na Eksodus 7:10,11, waar die Egiptiese wyses net soos Aäron hulle stawe slange laat word het. So kan die teoloog - Aäron - onder die filosowe - Egiptiese wyses - in ge- 
lykvormige gestalte en met dieselfde vermoë staan. Maar dan doen die staf van Aäron iets met die stawe van die wyses waartoe hulle stawe nie in staat is nie. Aäron se staf verslind die ander. Hoewel Aäron dus in dieselfde gestalte onder die wyses staan, gebeur daar iets wat ' $n$ teken van goddelike krag en denke is. So kan dit gebeur dat die teoloog iets sê wat die filosoof ook kon sê, maar dan nie as filosoof nie, maar as teoloog. As die teoloog so spreek, soos die filosoof ook sou kon spreek maar inderdaad nog nooit gespreek het nie, is dit geen prestasie van teologiese wetenskap nie, maar 'n wonder van Gods genade waaroor ' $n$ mens nie beskik nie, maar wat jy slegs kan ontvang.

Die een waarheid waarmee teoloog sowel as filosoof gekonfronteer word, het twee momente waarmee albei te doen het, maar in omgekeerde rigting. Daarom kom hulle ook teenoor mekaar te staan en loop dit op stryd uit. Die teoloog kyk en dink van die Skepper af na die skepsel. Op grond daarvan word daar ook weer gekyk en gedink langs die omgekeerde weg van die skepsel na die Skepper. Vir die teoloog is hierdie volgorde onomkeerbaar. Dis vir hom 'n saak van stantis et cadentis. Sodra hierdie volgorde omgedraai word, begin die valse teologie. Wat die filosoof betref, is die dinkorde primêr van onder na bo, van die skepsel na die Skepper, en vandaar weer terug na die primêre belangstelling: die mens. Wat die volgorde van hierdie momente in die waarheid betref, kan die teoloog geen konsessie maak nie. Die weg van die filosoof is vir hom afgesny. Dit kan vir hom alleen ' $n$ versoeking wees. As hy in sy teologiebeoefening die dinkweg en -wyse van die filosoof volg, word hy valse teoloog. Die teoloog kan nooit openlik of bedek ook filosoof wees nie. Dit beteken nie dat hy hom nie ook besig hou met die filosofie nie. Alleenlik, hy kan nie die dinkrigting van die filosoof vanuit die geskape werklikheid volg nie.

Dis vir Barth 'n ernstige vraag of hierdie twee ondernemings, dié van die filosoof wat by die mens begin, en dié van die teoloog wat by God begin, regmatig langs mekaar kan bestaan. Hy reken dat die waarheidsvraag wat aan albei gestel word, ook tussen hulle tree, en wel op so 'n wyse dat van die kant van die teoloog in elk geval nie toegegee kan word dat dit die een waarheid is wat hom in die een sowel as die ander volgorde van die momente ontsluit nie. Dis wel 'n pynlike vasstelling, maar van die kant van die teoloog moet dit gesê word. Hoewel dit vir die filosoof miskien naïef lyk, kan die teoloog alleen met ' $n$ belydenis antwoord waarom hy so praat. Hy kan alleen maar bely dat Jesus Christus die een ganse waarheid is deur Wie die weg van sy eie denke en spreke aangedui is en waardeur die weg van die filosoof vir hom afgesny is. Jesus Christus, die man van Nasaret, geen idee of simbool nie, is die een waarheid wat vir die hele wêreld skyn, vir teoloog en filosoof. Hy is die uitgangspunt en die doel van 
teologiese spreke. Barth kan hom dan ook net verbaas dat die filosoof nog altyd weë soek en hulle bewandel om die waarheid te vind, terwyl al sulke menslike weë tog ook vir die filosoof tot die verlede moet behoort. Hy sien dan ook eintlik net sin in die geskiedenis van die filosofie, sodat ' $n$ mens te wete kan kom hoe dat daar in die verlede oor sake filosofies gedink is.

Hoewel die weë van teoloog en filosoof skerp uitmekaar gaan, is hulle tog albei mense wat wetenskaplik besig is en daarom moet hulle koëksisteer. Volgens Barth sal dit goed wees vir beide om nie verder as hoorbreedte van mekaar te raak nie en wel om twee redes:

Hulle moet kennis neem van mekaar se werk, al is dit dan net om steeds duidelikheid te kry oor wat vir elkeen verbied en gebied is op sy bepaalde wetenskaplike weg.

Die een kan dalk onverwags by die ander iets vind wat vir hom leersaam kan wees.

As dit gebeur dat die een van die ander leer, beteken dit nie dat die een sy posisie teenoor die ander nou moet opgee nie. Dit beteken ook nie dat die ander in sy hele intensie nou verstaan word nie. Dit beteken slegs dat die een wat iets leer by die ander, op sy eie weg voortgehelp word. Hy moet hom ook nie vererg as hy sien dat die ander, ondanks die feit dat hy iets by hom geleer het, tog maar ongestoord op sy eie weg volhard nie. Die teoloog kan wel iets van die filosoof leer. Dit behoort die teoloog nie net krities nie, maar ook positief laat dink as hy die filosoof so fundamenteel besig sien in die volgorde van die waarheidsmomente waarin die mens die uitgangspunt en doelwit van sy hele onderneming is. Die filosoof as wêreldwyse onderstreep die probleem waarmee die teoloog hom, hoewel nie primêr nie, maar tog ook besig moet hou. Die tema van die teoloog is immers dat God die wêreld geskape het en hom so lief gehad het dat Hy sy enigste Seun vir daardie wêreld gegee het. Daar is 'n gevaar vir die teoloog dat hy in sy ywer vir die Woord van God, dalk die konkrete betrekking van God se Woord met die skepsel as die bondgenoot van God in sy verbond, met ander woorde dat hy die wêreld wat met God versoen is, nou nie juis vergeet nie, maar dit miskien te veel in die verbygaan behandel, miskien te weinig aandag daaraan gee. Hoewel die weë van teoloog en filosoof uitmekaar gaan, ook teenoor mekaar staan, kruis hulle mekaar tog ook weer in die gebied van die menslike bestaan waarmee albei hulle besig hou. Vir die filosoof is dit juis die primaat van belangstelling. Die teoloog sal onverstaanbaar bly as hy nie ook bevrydende uitsprake oor die menslike bestaan maak nie. Miskien beweeg die dinge van die filosoof vir die teoloog te weinig. Miskien vergeet die teoloog die wêreld van die natuur en die kultuur, die humaniteit, te maklik en miskien dink en praat hy te on-wêreldlik en on-menslik. Die filosoof is vir hom die herinnering daaraan dat hy dit nie moet doen nie. Want, sê 
Barth, hoe weet hy of dit nie dalk Jesus Christus, die Lig, Heer en Heiland van die wêreld is wat hom deur die filosoof as wêreldwyse tot orde wil roep nie? Christus wil hom dalk lei tot 'n godgeleerdheid, wat mooi beskou, nie teologie nie maar teantropologie behoort te wees. Laasgenoemde sal die dubbele probleem in die teologie, God en mens, meer tot sy reg laat kom.

Oor wat die filosoof van die teoloog kan leer, laat Barth hom nie uit nie. Hy kan maar net vir homself as teoloog praat. Hy veroordeel die filosoof ook nie omdat hy, wat die volgorde van die momente in die een waarheid, betref, die teenoorgestelde weg as die teoloog gaan nie. Hy wil alleen maar sê waarom daardie weg vir hom as teoloog verbode is. Hy laat dit aan die filosoof oor om self te sê hoe die Gees hom lei dat hy juis daardie weg in sy denke volg. So moet die filosoof ook self bepaal wat hy van die teoloog kan leer. Miskien, sê Barth, sal die filosoof nie juis ingenome wees met die lofrede oor hom as 'n wêreldwyse en oor wat die teoloog van hom kan leer nie. Miskien sien hy homself as baie meer as 'n wêreldwyse. Barth reken dat wat die een van die ander ook mag dink en sê, as elkeen maar opmerk dat binne die grense van hulle werk en bestaan daar wedersydse openheid is vir die beste in albei se arbeid, en as albei in die vertroue lewe dat die allerbeste wat die een van die ander kan hoor alleen van 'n ander plek gespreek kan word en dalk reeds gespreek is, behoort hulle vergenoegd te wees met wat hulle van mekaar kan en mag leer. In hierdie hoop moet hulle saam bestaan. Met verwysing na sy broer, sê hy - en kan ons vanuit die teologiese fakulteit met verwysing na die jubilaris in die departement wysbegeerte ook sê - as albei nog Christene is, sal die psalmwoord nog meer van toepassing wees: kyk hoe goed en hoe lieflik is dit dat broers ook saamwoon.

\section{Paul Tillich}

By Tillich kry 'n mens met 'n heeltemal ander opvatting te doen oor die betekenis van die filosofie vir die teologie. Waar Barth die filosofiese denke binne die teologie beskou as die begin van valse teologie, en slegs heel indirek praat oor die betekenis van die filosofie vir die teologie, daar wil Tillich, in die trant van Thomas van Aquino, 'n baie meer positiewe betekenis aan die filosofie nie net vir die teologie nie, maar in die teologie toeken. Filosofie is by hom ' $n$ integrale deel van die teologie en hy maak daar geen geheim van nie dat hy'n filosofiese teoloog wil wees. Ons het vantevore reeds gesê dat Tillich 'n beleid van rekonsiliasie ten opsigte van filosofie en teologie volg. 'n Mens kan met ewe veel reg ook praat van integrasie ten opsigte van die twee, hoewel Tillich self liewer praat van korrelasie. Met hierdie begrip dui Tillich sy hele teologiese sisteem aan. Om dit te 
verstaan, moet Tillich se beskouing oor die funksie van die teologie kortliks aangedui word. Dit bestaan uit twee momente:

Dit moet die waarheid van die Christelike boodskap formuleer, en

dit moet die geformuleerde waarheid interpreteer vir elke geslag in sy eie situasie.

Wat die interpretasie van die waarheid betref in elke situasie, is dit volgens Tillich belangrik om daarop te let dat die situasie van die mens juis die eksistensiële vrae bevat waarop hy 'n antwoord wil hê. Dis nie genoeg dat die teologie die ewige waarheid formuleer nie. Daarby moet nog 'n apologetiese moment kom. Onder apologetiese teologie verstaan Tillich juis die antwoord wat gegee moet word op die vrae wat ingesluit is in die situasie. Hierdie antwoorde word gegee in die krag van die ewige boodskap en met die middel wat deur die situasie voorsien word. Tillich bedoel eintlik daarmee dat die teologiese antwoord in filosofiese begrippe van die tyd gegee moet word omdat die moderne mens nie meer die klassieke teologiese begrippe ken nie. Kort saamgevat beteken die korrelasiemetode van Tillich dat daar teologiese antwoorde op filosofiese vrae gegee moet word. Anders gestel: die eksistensiële vrae wat daar aanwesig is in die menslike situasie, word deur die filosofie geanaliseer en aangetoon. Die filosofie antwoord egter nie hierdie vrae nie. Dis die verantwoordelikheid van die teologie. Omdat die teologie verstaanbaar moet spreek, moet die spreke aan twee vereistes voldoen:

Dit moet in 'n verstaanbare taal geskied, dit wil sê in die filosofiese taal van ' $n$ bepaalde tyd.

Dit moet antwoord gee op wesenlike vrae wat by die hoorder lewe. As 'n mens nie op so 'n wyse iemand aanspreek nie, praat jy oor sy kop heen.

As hier gepraat word van teologiese antwoorde op filosofiese vrae, bedoel Tillich nie dat noodwendig twee afsonderlike persone aan die woord is nie, die een ' $n$ filosoof en die ander' $n$ teoloog. Die teoloog en die filosoof kan in een persoon aanwesig wees. Die analise van die situasie geskied deur die teoloog wat op daardie oomblik filosoof is. As hy egter antwoord op die vrae, is hy nie langer filosoof nie, maar teoloog.

Die vraag kom onwillekeurig by ' $n$ mens op wat die rede is waarom Tillich filosofie en teologie so direk met mekaar in verbinding bring. Wat sou die grondliggende beskouing wees waarop hierdie hele sisteem gefundeer is? Die vermoede kan nie onderdruk word nie dat Tillich met ' $n$ voorstelling omtrent die verhouding van filosofie tot teologie werk wat op een of ander wyse 'n identiteitspunt tussen die twee veronderstel. Om hierdie identiteitspunt op te spoor, is dit nodig om noukeurig vas te stel wat die fundamentele vraag vir sowel filosofie as teologie by Tillich is. Filosofie is vir Til- 
lich ontologie. Ontologie is nie ' $n$ spekulatief-fantastiese poging om a la die metafisika 'n wêreld agter hierdie wêreld te vestig nie, maar dis ' $n$ ontleding van die struktuur van syn of bestaan waarmee ' $n$ mens te doen kry in elke ontmoeting met die werklikheid. Kennisbron vir die filosofie in sy vraag na die struktuur van die syn, is die rede. Die filosoof aanvaar ' $n$ analogie tussen ' $n$ universele, objektiewe logos van die werklikheid en 'n subjektiewe logos wat in hom werk. In sy diepste wese is teologie vir Tillich ook maar ontologie, want ook die teologie vra die vraag na die struktuur van die werklikheid. Objek van die teologie is wat Tillich noem slegs dit wat vir ons van "ultimate concern" is. Dit alleen bepaal 'n mens se bestaan of nie-bestaan. Maar nou kom die belangrike vasstelling van Tillich waarop sy bewering berus dat teologie ook ontologie is: wat vir ' $n$ mens van finale of laaste belang is, wat van "ultimate concern" is, moet tot die werklikheid as sodanig behoort, moet tot die syn/bestaan behoort, want anders sou 'n ontmoeting daarmee onmoontlik wees en sou dit ook nie van werklike belang wees nie. Dit kan ook nie 'n syn of bestaan te midde van ander wees nie, maar dit moet die grond van alle syn wees. Alleen dan kan dit bepalend wees van ons bestaan of nie-bestaan - "a matter of being or non-being". Waar die kennisbron vir die filosoof by die vraag na die struktuur van die syn die universele logos is, daar is dit vir die teoloog die konkrete logos wat 'n mens geword het, maar dit beteken geen teenstelling nie. In hierdie verband het Tillich ' $n$ baie fundamentele uitspraak gemaak wat bepalend is vir sy beskouing oor die verhouding tussen filosofie en teologie: "There is nothing in heaven and earth, or beyond them, to which the philosopher must subject himself except the universal logos of being as it gives itself to him in experience." (Systematic Theology, 1, p 32) Geen filosofie wat gehoorsaam is aan die universele logos kan dan ook in teenstelling met die konkrete logos staan wat vlees geword het nie. Net so belangrik, en min-of-meer in dieselfde kader val 'n volgende uitspraak: dis teen die eer van die teoloog en vir die filosoof onaanneembaar as die teoloog hom in ' $n$ filosofiese diskussie op 'n ander outoritiet as die rede beroep.

Sonder om in besonderhede te gaan, moet drie kritiese vrae aan Tillich gestel word.

Is daar eksegetiese grond vir die bewering dat God as "ultimate concern" die grond van die syn is? Die Bybel leer dat God die skepper van alle syn is en dat daar kwalitatiewe verskil tussen God en geskapene is. Kan grond en syn in die beskouing van Tillich wel so uit mekaar gehou word dat daar nie dalk panteïstiese verdenking kan ontstaan nie?

Is daar eksegetiese gronde vir die gelykstelling van die logos van die syn en die logos wat' $n$ mens geword het? Dit is tog duidelik dat die logos in die proloog van Johannes 'n persoon is van 
ewigheid af en wat in Jesus Christus ' $n$ mens geword het. Johannes, en tewens die hele Skrif, ken geen idee nie, maar slegs hierdie konkrete logos wat 'n mens geword het.

Is die teologiese sisteem van Tillich, filosofiese vrae en teologiese antwoorde, inderdaad uitvoerbaar? Behalwe dat die wesenlike menslike vrae van alle tye en in alle situasies die allerduidelikste aan die orde gestel is deur die beantwoording daarvan in die lewe en werk van die Woord wat 'n mens geword het, moet die vraag gestel word of die filosoof daarin sal berus om slegs behulpsaam te wees by die analise van die menslike situasie, en nie ook sal wil meespreek by die beantwoording van daardie vrae nie. Die gevaar is seker nie denkbeeldig nie dat die korrelasiemetode van Tillich die teologie filosofies kan laat buikspreek, en dit sal nie goed wees vir kerk en teologie nie. 